\title{
Isolation of Bacteria from Drill Cuttings, their Identification and Assessment of Destructive Potential
}

\author{
Elena G. Chernykh ${ }^{*}$ \\ 1 Federal State Budget Educational Institution of Higher Education, Industrial University of Tyumen, \\ Volodarskogo street 38, 652001 Tyumen, Russia \\ e-mail: chernyheg@tyuiu.ru
}

\begin{abstract}
The drilling of any oil and gas well is accompanied by the use of drilling fluids consisting of chemical reagents and materials of varying degrees of environmental hazard. The existing drilling waste disposal technologies are expensive, energy- and labor-intensive, and do not always contribute to the formation of environmentally friendly compounds. In this regard, the possibility of using destructor microorganisms capable of growing and exhibiting biochemical activity under the conditions of complex pollution, in an environment with a high content of hydrocarbons, surfactants and polymer additives capable of biodegrading these substances, is relevant. In connection with the foregoing, the search for new strains of bacteria for the disposal of drilling waste, which are resistant to the conditions of complex toxic effects of drill cuttings components and, at the same time, capable of providing a significant degree of detoxification of the reagents that are part of hydrocarbon-based solutions, is relevant.
\end{abstract}

Keywords: anionic surfactants, drill cuttings, carboxymethyl cellulose, diesel fuel, surfactants, cationic surfactants, oil-based drilling fluids, hydrocarbon-oxidizing microorganisms.

\section{INTRODUCTION}

It is known that when developing the methods for microbial utilization of various pollutants, including the components that make up drilling fluids and cuttings, it is advisable to screen for degrading microorganisms in contaminated habitats, because under such conditions, under the influence of selective pressure, microbial strains with a high destructive potential are formed.

The presence of microorganisms in oil reservoirs has long been established. On the example of various oil-bearing horizons, the existence of various metabolic groups of anaerobic microorganisms in the layers was established, i.e. the sulfate-reducing bacteria that reduce thiosulfate, $\mathrm{Fe}^{3+}$ and elemental sulfur, fermentative bacteria, acetogens and methanogens. Oil-bearing horizons, as a rule, are characterized by anoxic conditions, thus attracting the main attention of researchers. However, aerobic microorganisms also live in oil reservoirs, where they enter with injected water, drilling fluid during field development and in connection with the natural hydrodynamics of groundwater. In exploited oil fields, natural hydrocarbon-oxidizing microorganisms (hereinafter referred to as HOM) are the initial link in the microbial trophic chain that biodegrades oil.

The exploitation of oil fields, which until the moment of their development were practically not exposed to external influences, is accompanied by the entry of surface microorganisms, oxygen and some biogenic elements into the reservoir, which creates prerequisites for the development of specialized microbial communities, one of the main components of which are HOM.

\section{MATERIAL AND METHODS}

At present, a wide distribution of microorganisms in the waters of oil fields has been shown. Many authors searched for viable natural 
hydrocarbon-oxidizing microorganisms in the groundwater of deep wells (1900 and $3200 \mathrm{~m}$ ), which were calcium chloride thermal brines.

In this biotope, which is specific in terms of environmental factors, it was possible to find UOM and fungi. Drill cuttings (hereinafter referred to as BS) that have been at specialized sites of oil fields for a long time, can also serve as selective agents for the formation of HOM, as well as bacteria-destructors of various components of drilling fluids (Benka-Coker, Olumagin, 1995).

In connection with the foregoing, the microbial communities of several BS samples (BS 1 and $\mathrm{BS} \mathrm{2}$ ) with a high $\mathrm{pH}$ value (pH 9) and a degree of mineralization $(15 \%)$ were studied to identify microorganism-destructors of chemical reagents that are part of drilling fluids.

In the course of the studies, it was shown that the number of heterotrophic microorganisms isolated by direct seeding in the microbial communities of the analyzed samples of BSh 1 and BSh 2 was $1 \times 103$ and $8.9 \times 103$ cells/g, respectively (Table 1). Only aerobic bacteria of microbial communities were studied, because it is preferable to use aerobic bacteria for microbial utilization of BS located in special areas (sites, barns, etc.).

In connection with the multicomponent composition of BS, which includes, in addition to the hydrocarbon base, various chemical compounds, such as surfactants (hereinafter referred to as surfactants), starch, carboxymethyl cellulose (hereinafter referred to as $\mathrm{CMC}$ ), etc., for a more detailed characterization of microbial communities, BS was evaluated in terms of the number of bacteria that hydrolyze starch, CMC, as well as microorganisms-destructors of nonionic surfactants (hereinafter referred to as nonionic surfactants), anionic surfactants (hereinafter referred to as surfactants) and natural hydrocarbon-oxidizing microorganisms (hereinafter referred to as HOM.

The content of microorganisms of various physiological groups in drill cuttings are presented in Table 1.

As it was established (Table 1), the BS 2 sample contained: $\mathrm{UOM}-6.1 \times 103$ and $8.8 \times 102$ cells/g of microorganisms that hydrolyze starch. At the same time, microorganisms-destructors of sintanol, sulfonol and CMC were not detected. The microbial community of sample BSh 1 did not differ in diversity; here, HOM, destructors of nonionic surfactants, surfactants, CMC and starch were not detected in a noticeable amount.

When bacteria were isolated by using the method of enrichment cultivation, hydrocarbon substrates were used as the only source of carbon and energy, to which, presumably, the BS microorganisms could be partially adapted; these are drilling fluids based on mineral oil (BR 1) and diesel fuel (hereinafter - DF) (BR 2). The data on the total number of heterotrophic microorganisms and the content of HOM, microorganisms-destructors of nonionic surfactants, surfactants, as well as the bacteria that hydrolyze starch and CMC, obtained from the analysis of enrichment cultures using the BS samples, are presented in Table 1 .

The results of the experiments showed that the addition of selective food sources to the cultivation medium increased the number of bacteria

Table 1. The content of microorganisms of various physiological groups in drill cuttings

\begin{tabular}{|c|c|c|c|c|c|c|c|}
\hline Samples & $\begin{array}{l}\text { Extraction methods } \\
\text { microorganisms }\end{array}$ & \multicolumn{6}{|c|}{ Number of bacteria, cells/g (ml) } \\
\hline \multirow{4}{*}{ BSh 1} & \multirow[t]{2}{*}{ 1. Direct seeding } & Heterotrophic & UOM & $\begin{array}{l}\text { Hydrolyzing } \\
\text { starch }\end{array}$ & $\begin{array}{l}\text { Hydrolyzing } \\
\text { CMC }\end{array}$ & $\begin{array}{c}\text { Destructors } \\
\text { nonionic } \\
\text { surfactants }\end{array}$ & $\begin{array}{c}\text { Destructors } \\
\text { AS }\end{array}$ \\
\hline & & $1.0 \times 10^{3} \pm 0.30$ & $<50 \pm 0.44$ & $<50 \pm 0.00$ & $<50 \pm 0.00$ & $<50 \pm 0.00$ & $<50 \pm 0.00$ \\
\hline & $\begin{array}{l}\text { 2. Cumulative } \\
\text { cultivation (+BR 1) }\end{array}$ & $2.8 \times 10^{5} \pm 0.58$ & $4.4 \times 10^{4} \pm 0.22$ & $<50 \pm 0.00$ & $<50 \pm 0.00$ & $<50 \pm 0.00$ & $<50 \pm 0.00$ \\
\hline & $\begin{array}{l}\text { 3. Cumulative } \\
\text { cultivation (+BR 2) }\end{array}$ & $2.0 \times 10^{4} \pm 0.22$ & $1.1 \times 10^{4} \pm 0.44$ & $4.3 \times 10^{2} \pm 0.42$ & $<50 \pm 0.44$ & $<50 \pm 0.00$ & $<50 \pm 0.00$ \\
\hline \multirow{3}{*}{ BSh 2} & 1. Direct seeding & $8.9 \times 10^{3} \pm 0.38$ & $6.1 \times 10^{3} \pm 0.34$ & $8.8 \times 10^{2} \pm 0.46$ & $<50 \pm 0.54$ & $<50 \pm 0.00$ & $<50 \pm 0.00$ \\
\hline & $\begin{array}{l}\text { 2. Cumulative } \\
\text { cultivation (+BR 1) }\end{array}$ & $1.4 \times 10^{5} \pm 0.38$ & $4.3 \times 10^{4} \pm 0.45$ & $6.9 \times 10^{3} \pm 0.58$ & $<50 \pm 0.00$ & $<50 \pm 0.00$ & $<50 \pm 0.00$ \\
\hline & $\begin{array}{l}\text { 3. Cumulative } \\
\text { cultivation (+BR 2) }\end{array}$ & $1.8 \times 10^{5} \pm 0.40$ & $1.6 \times 10^{4} \pm 0.28$ & $4.2 \times 10^{3} \pm 0.52$ & $<50 \pm 0.00$ & $<50 \pm 0.00$ & $<50 \pm 0.00$ \\
\hline
\end{tabular}

Note: " $<50$ " means that when bacteria were seeded from a 1:5 dilution, microorganisms of the corresponding groups were not detected. 
of certain above-mentioned groups compared with the direct seeding of microorganisms from BS. In the mud sample BSh 1, the total content of heterotrophic bacteria increased 10 times when it was cultivated with drilling fluid based on diesel fuel and significantly higher - by two orders of magnitude - with a solution based on mineral oil. The use of these oil-based drilling fluids (hereinafter referred to as OBM) as nutrient substrates contributed, to a large extent, to the development of the UOM group. With direct seeding from this sample, HOM could not be detected, whereas, with accumulation cultivation, the number of HOM reached the following values: $1.1 \times 104$ and $4.4 \times 104$ cell $\mathrm{s} / \mathrm{ml}$ when drilling fluids based on diesel fuel and mineral oil were introduced into the medium, respectively. In the BSh 1 sample, compared with direct seeding, the number of microorganisms that hydrolyze starch, when cultivated with a model solution based on diesel fuel (BR 2), increased by 2 orders of magnitude, while the addition of drilling fluid based on mineral oil (BR 1) did not affect this group of bacteria.

In the BSh 2 sample, the total number of heterotrophic microorganisms, as well as in BSh 1, reached 105 cells $/ \mathrm{ml}$ when it was cultivated with solutions of BR 1 and BR 2, the number of UOM was 104 cells $/ \mathrm{ml}$, the number of bacteria that hydrolyze starch. Both drilling fluids, which we used as selective reagents, equally contributed to the development of microorganisms of different groups contained in the BSh 2 sludge, in contrast to the BSh 1 sample, where the drilling fluid based on mineral oil stimulated the growth of heterotrophic bacteria and UOM to a greater extent.

It should be noted that the additions to the cultivation medium in the form of drilling solutions did not stimulate the development of bacteria-destructors of nonionic surfactants, surfactants, and CMC in both BS samples, which may be due to a rather low concentration of these reagents in the solutions or their toxicity.

Thus, it can be noted that aerobic heterotrophic bacteria are contained in BS in different amounts, which is probably due to the specific environmental conditions, as well as the different composition of the cuttings and, as a result, the presence of various sources of nutrients. Among the bacteria included in the BS communities, UOM, starch hydrolyzing microorganisms, are found. This creates the prerequisites for the isolation of BS reagents and drilling fluids from such communities of active destructors, including those hazardous to the environment.

\section{RESULT}

\section{Morphological and physiological-biochemical characteristics of isolated cultures}

As a result of the experiments, 7 pure microbial cultures were isolated from $\mathrm{BS}$, which were later studied in more detail.

By direct seeding, a strain with the laboratory code NSh was isolated from the BSh 1 sample, and OBR 1 was isolated from the BSh 2 sample.

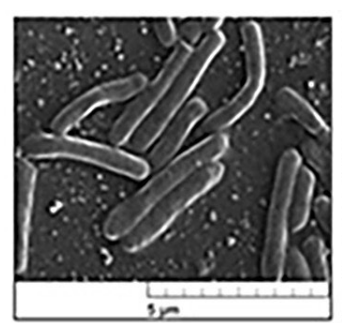

NS

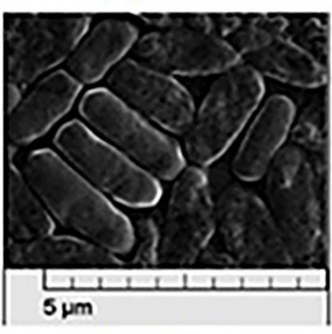

OBR 3.2

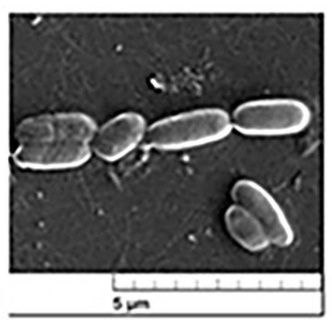

OBR 1.1

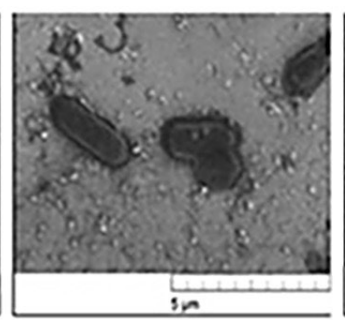

OBR 3.1

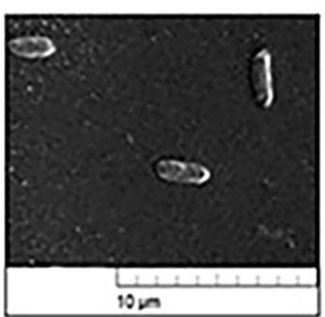

OBR 1

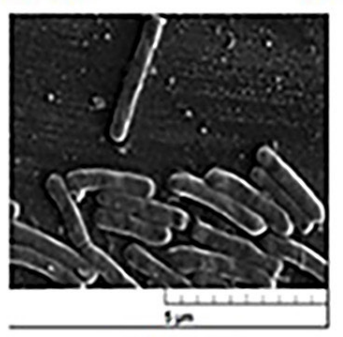

OBR 3.3

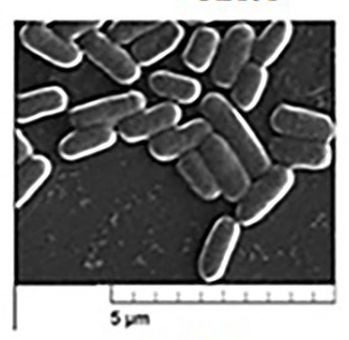

OBR 4.1

Figure 1. Images of cells of isolated cultures at the age of 24 hours, obtained using transmission electron microscopy 
Table 2. Results of the performed analyzes

\begin{tabular}{|c|c|c|c|c|c|c|}
\hline \multirow{2}{*}{$\begin{array}{c}\text { Laboratory } \\
\text { code of cultures }\end{array}$} & \multicolumn{6}{|c|}{ Main properties } \\
\hline & Microscopic study & Growth on MPB & $\begin{array}{l}\text { Growth on } \\
\text { MPA }\end{array}$ & $\begin{array}{l}\text { Relation to } \\
\text { oxygen }\end{array}$ & $\begin{array}{l}\text { Temperature } \\
\text { optimum }\end{array}$ & $\begin{array}{c}\text { Characteristics of the } \\
\text { colonies }\end{array}$ \\
\hline NS & $\begin{array}{l}\text { Gram-variable rods: at } \\
\text { the age of } 24 \text { hours - gram- } \\
\text { negative long or slightly } \\
\text { curved, located singly and } \\
\text { in pairs; } 48 \mathrm{~h} \text { - gram -posi- } \\
\text { tive short. } \\
\text { Endospores are ellipsoidal, ly- } \\
\text { ing subterminally. Spores } \\
\text { are cylindrical. }\end{array}$ & $\begin{array}{l}\text { When incubated for 24- } \\
48 \text { hours without shaking } \\
\text { there is a uniform turbidity of } \\
\text { the broth, the formation of a } \\
\text { film, sediment }\end{array}$ & $\begin{array}{l}\text { Good growth } \\
\text { on } \\
\text { the first day at } \\
28^{\circ} \mathrm{C}\end{array}$ & $\begin{array}{l}\text { Facultative } \\
\text { anaerobe }\end{array}$ & $20-30^{\circ} \mathrm{C}$ & $\begin{array}{l}\text { Opaque cream with a slight- } \\
\text { ly convex shiny surface and } \\
\text { smooth edges; } \\
\text { d colonies - } 1.0-3.0 \mathrm{~mm}\end{array}$ \\
\hline OBR 1.1 & $\begin{array}{l}\text { Gram-positive rods, lo- } \\
\text { cated singly and in } \\
\text { the form of chains of two or } \\
\text { three cells. Endospores are } \\
\text { ellipsoidal, lying subterminally } \\
\text { controversy } \\
\text { ellipsoidal. }\end{array}$ & $\begin{array}{l}\text { When incubated for } 24- \\
48 \text { hours without shaking, a } \\
\text { precipitate is observed with } \\
\text { a uniform } \\
\text { clouding of the environment }\end{array}$ & $\begin{array}{l}\text { Good growth } \\
\text { on } \\
\text { the first day at } \\
28^{\circ} \mathrm{C}\end{array}$ & $\begin{array}{l}\text { Facultative } \\
\text { anaerobe }\end{array}$ & $\begin{array}{c}20-30^{\circ} \mathrm{C} \\
\text { (able to } \\
\text { grow at } 12^{\circ} \mathrm{C} \text { ) }\end{array}$ & $\begin{array}{l}\text { Opaque cream with a slight- } \\
\text { ly domed shiny surface and } \\
\text { smooth edges; } \\
\text { d colonies }-2.0-4.0 \mathrm{~mm}\end{array}$ \\
\hline OBR 3.1 & $\begin{array}{l}\text { Gram-positive rods, located } \\
\text { singly and in pairs. Endo- } \\
\text { spores are ellipsoidal, ly- } \\
\text { ing subterminally. controversy } \\
\text { ellipsoidal. }\end{array}$ & $\begin{array}{l}\text { Precipitation occurs when } \\
\text { incubated for } 24- \\
48 \text { hours without shaking. }\end{array}$ & $\begin{array}{l}\text { Good growth } \\
\text { on } \\
\text { the first day at } \\
28^{\circ} \mathrm{C}\end{array}$ & $\begin{array}{l}\text { Facultative } \\
\text { anaerobe }\end{array}$ & $20-30^{\circ} \mathrm{C}$ & $\begin{array}{l}\text { Opaque white with a slight- } \\
\text { ly convex shiny surface and } \\
\text { smooth edges; } \\
\text { d colonies - } 2.0-3.5 \mathrm{~mm}\end{array}$ \\
\hline OBR 1 & $\begin{array}{l}\text { Gram-negative straight } \\
\text { rods located singly. } \\
\text { Dispute does not form }\end{array}$ & $\begin{array}{l}\text { When incubated for } 24- \\
48 \text { hours without shaking } \\
\text {, film formation is observed. } \\
\text { on the surface }\end{array}$ & $\begin{array}{l}\text { Good growth on } \\
\text { the first day at } \\
28^{\circ} \mathrm{C}\end{array}$ & Aerobe & $20-42^{\circ} \mathrm{C}$ & $\begin{array}{l}\text { Round shape, with a rough } \\
\text { surface, shiny, white- } \\
\text { cream color with smooth } \\
\text { edges, dry consistency; } \\
\text { d colonies - } 2.0-4.0 \mathrm{~mm}\end{array}$ \\
\hline OBR 3.2 & $\begin{array}{l}\text { Gram-positive straight rods } \\
\text { located singly. Generates } \\
\text { controversy. Endospores are } \\
\text { spherical, lying terminally } \\
\text { in swollen sporangia. }\end{array}$ & $\begin{array}{l}\text { When incubated for } 24- \\
48 \text { hours without shaking } \\
\text { film formation is observed } \\
\text { on the surface of the me- } \\
\text { dium }\end{array}$ & $\begin{array}{l}\text { Good growth } \\
\text { on the first day } \\
28^{\circ} \mathrm{C}\end{array}$ & Aerobe & $20-35^{\circ} \mathrm{C}$ & $\begin{array}{l}\text { Small rounded, smooth, } \\
\text { shiny, white, homogeneous, } \\
\text { with smooth edges, mu- } \\
\text { cous consistency; } \\
\text { d colonies - } 1.0-3.0 \mathrm{~mm}\end{array}$ \\
\hline OBR 3.3 & $\begin{array}{l}\text { Gram-positive long rods, } \\
\text { located both singly and } \\
\text { in pairs. } \\
\text { Generates controversy. Endo- } \\
\text { spores are ellipsoidal, ly- } \\
\text { ing subterminally. controversy } \\
\text { cylindrical. }\end{array}$ & $\begin{array}{l}\text { When incubated for } 24- \\
48 \text { hours without shaking, a } \\
\text { precipitate is observed with } \\
\text { a uniform } \\
\text { turbidity of the environment. }\end{array}$ & $\begin{array}{l}\text { Good growth } \\
\text { on the } \\
\text { first day at } \\
28^{\circ} \mathrm{C}\end{array}$ & $\begin{array}{l}\text { Facultative } \\
\text { anaerobe }\end{array}$ & $20-30^{\circ} \mathrm{C}$ & $\begin{array}{l}\text { Opaque white with } \\
\text { a smooth luster } \\
\text { surface and smooth edges; } \\
\text { d colonies - } 1.0-3.0 \mathrm{~mm}\end{array}$ \\
\hline OBR 4.1. & $\begin{array}{l}\text { Gram-negative straight rods } \\
\text { with rounded ends, lo- } \\
\text { cated singly. Does not form } \\
\text { a dispute. }\end{array}$ & $\begin{array}{l}\text { When incubated for } 24- \\
48 \text { hours without shaking } \\
\text { precipitate formation is } \\
\text { observed }\end{array}$ & $\begin{array}{l}\text { Good growth } \\
\text { on } \\
\text { the first day at } \\
28^{\circ} \mathrm{C}\end{array}$ & $\begin{array}{l}\text { Facultative } \\
\text { anaerobe }\end{array}$ & $20-42^{\circ} \mathrm{C}$ & $\begin{array}{l}\text { Large round- } \\
\text { ed, smooth, shiny, white, } \\
\text { opaque, homogeneous, with } \\
\text { smooth edges, mucous con- } \\
\text { sistency; } \\
\text { d colonies - } 3.0-5.0 \text { mm. Af- } \\
\text { ter } 48 \text { hours of incubation, } \\
\text { the colonies become slight- } \\
\text { ly pink } \\
\text { shade. }\end{array}$ \\
\hline
\end{tabular}

Using the enrichment cultivation method, from the BSh 1 variant, where the drilling fluid BR 2 was the only source of carbon, samples were isolated (hereinafter referred to as the OBR): OBR 3.1, OBR 3.2, and OBR 3.3; when using drilling fluid BR 1, OBR 1.1 was isolated from this sample; from sample BSh 2 with drilling fluid BR 2 - OBR 4.1.

In order to identify the isolated strains, research was carried out to study their cultural-morphological and physiological-biochemical characteristics. The results of the analyses performed are presented in tables 2 and 3.

The main diagnostic morphological and morphometric characteristics of microbial cells were obtained using electron microscopy (Figure 1).
On the basis of the studies carried out, the cultures isolated from drill cuttings were identified based on the results of a comparative analysis of cultural-morphological, morphometric and physiological-biochemical characteristics in accordance with the criteria for bacterial differentiation proposed in the 9th edition of the manual "Burgey's Key to Bacteria" (1997), as well as in accordance with the principles molecular typing of prokaryotic cells as: Bacillus circulans NSh; $B$. firmus OBR 1.1; B. firmus OBR 3.1; Solibacillus silvestris 3.2, B. circulans OBR 3.3, Halomonas sp. ABR 1 and Erwinia rhapontici ABR 4.1.

Therefore, from the BS 1 sample by direct seeding and with the help of accumulative cultivation, the following were isolated: Bacillus 
circulans NS; B. firmus OBR 1.1; B. firmus OBR 3.1; Solibacillus silvestris 3.2 and $B$. circulans OBR 3.3. The following cultures were isolated from the BSh 2 sample: Halomonas sp. ABR 1 and Erwinia rhapontici ABR 4.1.

So, from the sample BS 1 by direct seeding and with the help of accumulative cultivation, the following were isolated: Bacillus circulans NS; $B$. firmus OBR 1.1; B. firmus OBR 3.1; Solibacillus silvestris 3.2 and $B$. circulans OBR 3.3. The following cultures were isolated from sample BSh 2: Halomonas sp. ABR 1 and Erwinia rhapontici ABR 4.1.

Saprotrophic spore-forming bacteria (bacilli) are common inhabitants of soils; they are actively involved in the processes associated with the decomposition of organic substrates. It has been shown that under the conditions of oil pollution in soils, active reproduction of bacilli cells occurs, and species characteristic of soils with weak mineralization processes multiply to a large extent, and the diversity of the species composition of the spore-forming microbiota increases (Kireeva and Rafikova, 2007).

The authors (Bento et al., 2003) isolated from the soils contaminated with diesel fuel (California, USA) a HOM consortium based on Bacillus cereus, Bacillus sphaericus, Bacillus fusiformis, Bacillus pumilus, Acinetobacter

Table 3. Physiological and biochemical properties of isolated cultures

\begin{tabular}{|c|c|c|c|c|c|c|c|}
\hline \multirow{2}{*}{ Signs } & \multicolumn{7}{|c|}{ Laboratory code of cultures } \\
\hline & NS & OBR 1.1 & OBR 3.1 & OBR 3.2 & OBR 3.3 & OBR 1 & OBR 4.1 \\
\hline Acid resistance & - & - & + & + & - & - & - \\
\hline Mobility & + & + & + & + & + & + & + \\
\hline \multicolumn{8}{|c|}{ Products } \\
\hline Oxidases & - & - & - & - & - & + & - \\
\hline Catalase & + & + & + & + & + & + & + \\
\hline $\mathrm{H}_{2} \mathrm{~S}$ & + & + & + & + & + & + & $+/-$ \\
\hline Indole & - & - & - & - & - & - & - \\
\hline $\mathrm{NH} 3$ & - & - & - & $+/-$ & - & $+/-$ & + \\
\hline Nitrate reductase & + & + & + & - & - & - & + \\
\hline Phenylalanine deaminase & + & - & - & - & - & - & - \\
\hline Casein & $+/-$ & - & $+/-$ & $+/-$ & $+/-$ & $+/-$ & - \\
\hline Gelatinase & $+/-$ & - & + & - & $+/-$ & - & $+/-$ \\
\hline Arginine hydrolases & - & - & - & - & - & $+/-$ & - \\
\hline Lysine decarboxylases & - & - & - & - & - & $+/-$ & - \\
\hline Ornithine decarboxylases & - & - & - & - & - & - & - \\
\hline Lecithinase & - & - & - & - & - & - & - \\
\hline Ureases & - & - & - & - & - & $+/-$ & - \\
\hline Hydrolysis of starch & $+/-$ & + & - & $+/-$ & - & $+/-$ & - \\
\hline Utilization of citrate & - & - & - & $+/-$ & - & - & - \\
\hline Growth at $10^{\circ} \mathrm{C}$ & - & + & - & - & - & - & - \\
\hline Growth at $42^{\circ} \mathrm{C}$ & + & + & + & - & + & + & + \\
\hline \multicolumn{8}{|c|}{ Oxidizes } \\
\hline Glucose & OF & OF & OF & 0 & OF & $\mathrm{O}$ & $\mathrm{F}$ \\
\hline Lactose & $\mathrm{F}$ & OF & $\mathrm{F}$ & 0 & OF & $\mathrm{O}$ & - \\
\hline Arabinose & OF & $\mathrm{O}$ & - & $\mathrm{O}$ & OF & - & $\mathrm{F}$ \\
\hline Sucrose & - & $\mathrm{O}$ & OF & $\mathrm{O}$ & OF & $\mathrm{O}$ & $\mathrm{O}$ \\
\hline Maltose & - & $\mathrm{O}$ & $\mathrm{O}$ & O & O & - & $\mathrm{F}$ \\
\hline Mannitol & 0 & $\mathrm{O}$ & OF & $\mathrm{O}$ & $\mathrm{F}$ & $\mathrm{O}$ & - \\
\hline Xylose & 0 & 0 & - & 0 & O & - & - \\
\hline Fructose & 0 & - & - & - & 0 & - & - \\
\hline Galactose & 0 & 0 & - & 0 & 0 & $\mathrm{O}$ & $\mathrm{F}$ \\
\hline Voges-Proskauer reaction & - & - & - & - & - & - & - \\
\hline
\end{tabular}

Note: "O" - oxidation, "F" - fermentation, "-" - no reaction. 
junii, and Pseudomonas sp. It is known (Netrusov and Kotova, 2006; Gosmanov et al., 2011) that the formation of spores for bacteria is a factor in the preservation of the species under unfavorable conditions (changes in temperature, $\mathrm{pH}$ of the environment, lack of nutrients, the presence of toxins, etc.).

The fact that the representatives of sporeforming microorganisms dominated among the bacteria isolated from BS indicates their wide adaptive potential, which is associated, among other things, with spore formation.

\section{Substrate spectrum of bacteria isolated from drill cuttings}

Due to the fact that the hydrocarbon component of OBM poses a great environmental hazard to the environment as well as requires rapid and complete destruction, the bacteria isolated from the microbial communities of BS were studied for the ability to degrade petroleum hydrocarbons.

When studying the destructive potential of microorganisms isolated from $\mathrm{BS}$, as the only source of carbon and energy, crude oil, vaseline oil, diesel fuel, drilling fluid based on mineral oil, a number of individual hydrocarbons were added to the agar mineral medium: n-alkanes (hexane, heptane, octane, decane, hexadecane), aromatics (benzene, toluene, xylene, cumene, nitrobenzene), alicyclic compounds (cyclohexane) and PAHs (naphthalene).

All studied bacteria were characterized by a distinct growth on all used oil products (Figure 2 ), with the exception of the S. silvestris OBR

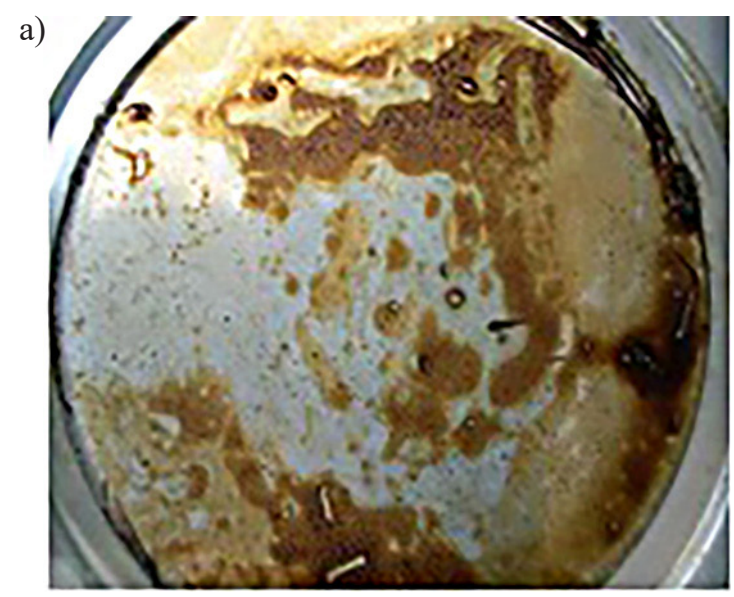

3.2 strain, whose growth was not observed in the variants with vaseline oil and diesel fuel.

Growth on oil and oil products suggests that bacteria have appropriate enzyme systems for the degradation of hydrocarbons and mechanisms to suppress the toxic effect of oil. Oil contains thousands of substances in its composition, and the share of a few of them reaches at least one percent. Obviously, for effective oil degradation, the strain must be able to compensate for the toxic effect of the pollutant and be able to use at least some of the oil components as sources of carbon and energy.

On individual hydrocarbons, the studied microorganisms grew with different intensity. Among them, several crops can be distinguished (B. firmus OBR 1.1 ; B. firmus OBR 3.1 ; B. circulans OBR 3.3 and B. circulans NS), which actively used all the oil products and individual hydrocarbons were tested for growth (Figure 3). The relatively greater width of the spectrum of hydrocarbons consumed by these microorganisms can be interpreted as their relatively greater ability to consume pollutant oil products.

All the studied bacteria were unable to assimilate cyclohexane as the only source of carbon, which indicates the high toxicity of naphthenic hydrocarbons for these microorganisms. Bacteria also did not grow on a mineral medium with naphthalene, which acts as the only source of carbon and energy, at the same time, on MPA with naphthalene at a concentration of $0.4 \mathrm{mg} / \mathrm{l}$, all cultures showed good growth on the first day, which indicates the stability of the data bacteria to naphthalene at this concentration.

Melnikov and Karaseva (2005) reported that the bacterial strains isolated from oil-contaminated soil most often grew on n-alkanes

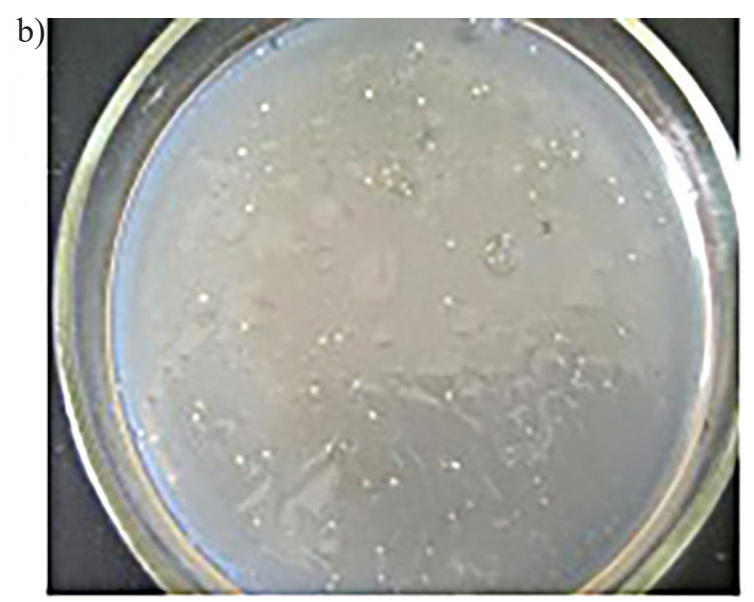

Figure 2. Growth of B. firmus OBR 3.1 on a mineral medium with drilling mud (a) and vaseline oil (b) as the only source of carbon and energy 

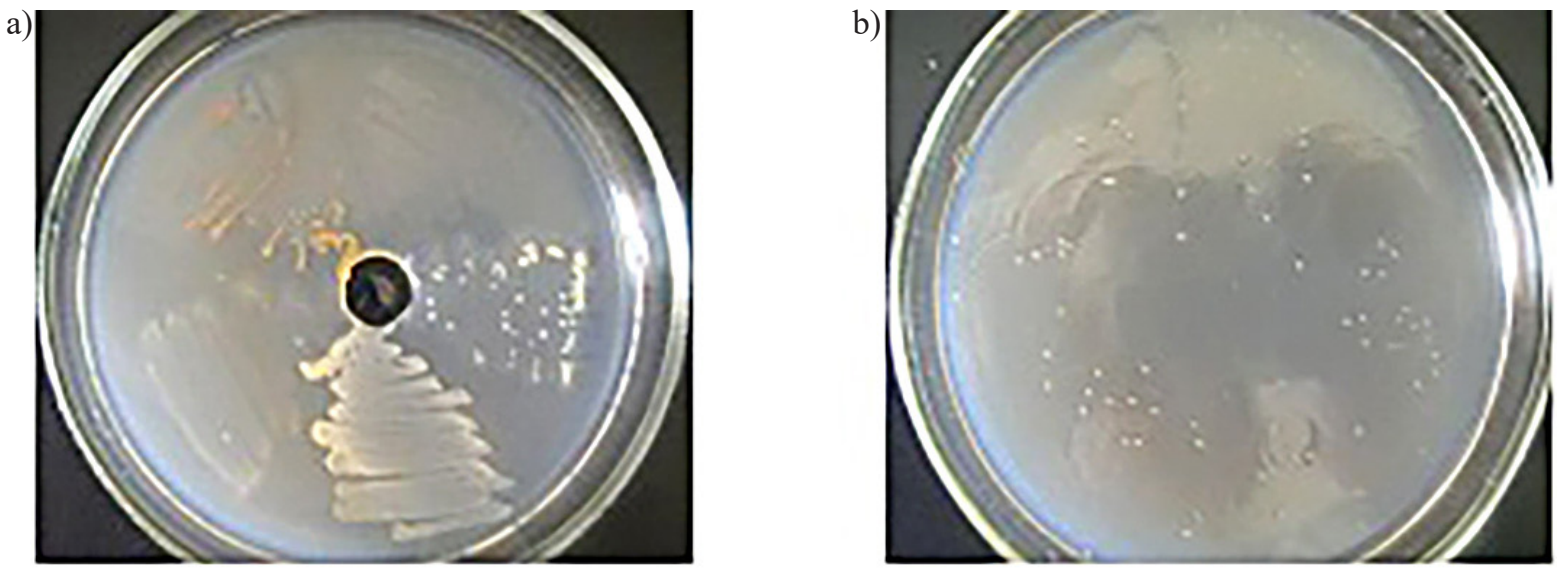

Figure 3. Growth of B. circulans OBR 3.3 on a mineral medium with (a) hexadecane and (b) DT as the only source of carbon and energy

$(14.5-33.3 \%)$, much less frequently on aromatic hydrocarbons $(0-4.3 \%)$.

It should be noted that, despite the high toxicity of aromatic hydrocarbons, in particular, nitrobenzene (Taran, 2012; Elder and Kelly, 1994), the microbial strain B. firmus OBR 1.1 was characterized by a barely pronounced growth on nitrobenzene and distinct growth on toluene. The B. firmus OBR 3.1, S. silvestris OBR 3.2, and B. circulans OBR 3.3 microorganisms were characterized by distinct growth on the medium with benzene.

Thus, the obtained results testified to the diversity of trophic possibilities of the isolated microorganisms in relation to oil products and individual hydrocarbons, components of BS.

\section{Quantitative assessment of the destruction of petroleum products by the bacteria isolated from drill cuttings}

It is known that the most common dispersion media in OBM are oil, diesel fuel and mineral oil (Soloviev, 2003; Smirnova, 2011; Young, 1994). Therefore, the destructive activity of the isolated microorganisms was studied in relation to these dispersion media (petroleum products), which were added to the M9 mineral medium as the only source of carbon and energy at a concentration of $0.4 \%$ (by weight).

The destructive activity of bacteria was determined after 10 days of cultivation, according to the residual content of petroleum hydrocarbons in the mineral medium by using the gravimetric method (RD 52.18.647-2003. Methodological instructions..., 2003).
After 10 days, in the control samples (without the addition of bacteria), a slight decrease in the studied dispersion media was observed, which is due to physicochemical processes occurring over time in the medium with oil products (photolysis, hydrolysis, etc. without the participation of biota) (Ivanenko, 2006; Shukla, 1990). The amount of oil at the same time decreased by 7 , mineral oil by 8 , diesel fuel - by $15 \%$.

The destructive activity of bacteria was 28 $40 \%$ in different strains. The maximum destructive activity towards oil was observed in strains B. firmus OBR 3.1 (Figure 4a) and B. circulans NSh (38\%) (Figure 4b), as well as in Halomonas sp. OBR $1-40 \%$.

Differences are visualized in Figure 4. In a liquid medium with oil as the only source of carbon and energy and microbial strains, there is no oiliness on the walls of the flask, the medium becomes cloudy due to bacterial growth; the oil is in a dispersed state, in the form of a finely dispersed emulsion, in granules of different sizes. In the control flask without bacteria, the medium is transparent; the oil is without any changes in color and state of aggregation. The fact of oil dispersion suggests that these strains under certain cultivation conditions are able to synthesize and secrete surfactants that emulsify oil.

If the destructive activity of bacteria isolated from BS is compared with the activity of other oil degrading cultures, the following can be noted: in a model experiment Loginova et al. (2004) showed that the biological product "Bacispecin" based on the strain Bacillus sp. 739 is able to utilize oil in $40-60 \%$ in 30 days, depending on the degree of pollution. In the work of Klyuyanova (2009) it was found that the B. firmus SDS-1 strain isolated 

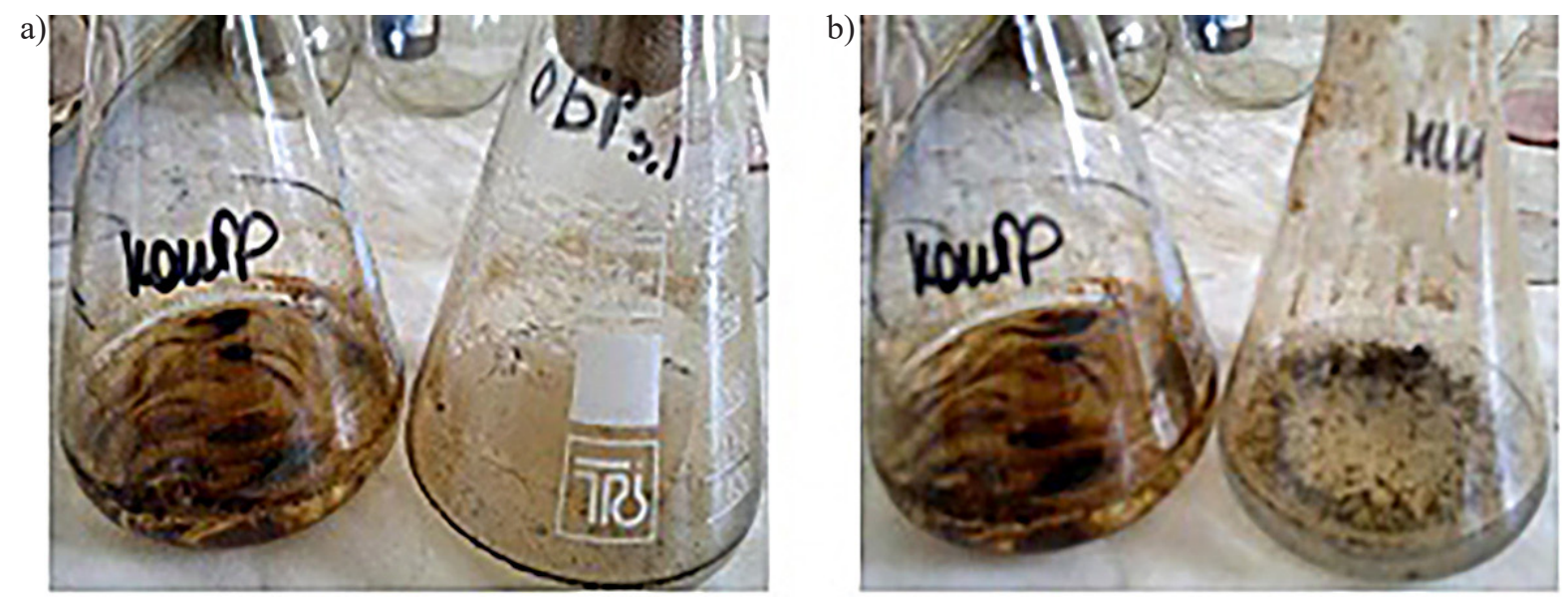

Figure 4. Visual assessment of the nature of bacterial growth in a liquid medium with oil as the only source of carbon and energy compared to the control (flask on the left): $\mathrm{a}-$ B. firmus OBR $3.1 ; \mathrm{b}-$ B. circulans NSh

from oil-contaminated soil is able to utilize oil in a liquid medium in up to $82 \%$ in 10 days of cultivation. Plotnikova (2010) showed in her studies that Halomonas sp. is able to assimilate aromatic and polyaromatic hydrocarbons, which are contained in the composition of oil, up to $55 \%$. The bacterial strains isolated by Ilyina et al. (2003) from oil-contaminated soils showed from $21 \%$ to $30.5 \%$ destruction of total petroleum hydrocarbons in 15 days of cultivation They were selected as the best among the other 30 isolates. The biological product "COBE-10" was created based on them. Among these strains were: Bacillus sp., Rhodococcus sp., Providencia sp., Citrobacter sp.

Thus, the destructive activity of the isolated microorganisms in relation to petroleum hydrocarbons, although not too high, is at the same time comparable with the literature data.

In relation to DT, two strains, i.e. $B$. circulans OBR 3.3 and B. circulans NSh, showed a noticeable destructive activity. The total content of hydrocarbons during the cultivation of these strains decreased by 35.5 and $25 \%$, respectively. The results obtained are consistent with the literature data. In the experiments of Astrov et al. (1998) showed a high destructive activity of the Bacillus sp. strains, which, in association with Pseudomonas sp. and Micrococcus sp., are able to reduce the concentration of DT to $0.01 \mathrm{mg} / 1$ and below. However, all other strains studied did not show significant destructive activity in relation to DT.

It is known that simple unbranched n-alkanes predominate in DT (Heath et al., 1993). Although the metabolism of n-alkanes (C6-C12) is possible, many of them act as solvents, destroying cells through partial solubilization of membrane phospholipids, thus exerting a toxic effect on many microorganisms (Cunningham and Philp, 2000). It is possible that the bacteria studied also turned out to be susceptible to the toxic effect of low molecular weight alkanes of diesel fuel.

The results of a quantitative analysis of mineral oil degradation showed that in the samples with $B$. firmus OBR 3.1 and B. circulans NSh, a decrease in hydrocarbons was observed, by $39 \%$ and $35 \%$, respectively.

These results coincided with the high destructive activity of these cultures in relation to oil. Cultivation of other microbial strains did not lead to significant degradation of mineral oil. The low destructive potential of degrading bacteria in relation to the studied mineral oil (Luxe standard $15 \mathrm{~W}-40$ ) can be associated with the multicomponent composition of this oil product, which, in addition to high-molecular hydrocarbons, includes various additives, such as phenolates, dithiophosphates and alkyl dithiophosphates of various metals (Karaulov and Khudoliy, 2000).

\section{CONCLUSIONS}

Thus, the experiment showed that all bacteria isolated from BS are good at assimilating oil as the only source of carbon and energy, which may be related to the sources of their release (oil wells) and, as a result, their long-term adaptation to this substrate as a source of nutrition.

On the basis of the results of the conducted experiment, the following bacteria can be identified as promising decomposers of petroleum 
hydrocarbons: B. circulans NSh degrades oil, diesel fuel and mineral oil in 10 days of cultivation in a liquid medium - by 38,25 and $35 \%$, respectively; B. firmus OBR 3.1 - oil and mineral oil by 38 and $39 \%$; Halomonas sp. OBR 1 - oil - by $40 \%$; B. circulans OBR 3.3 - DT - by $35.5 \%$.

The fact that not all bacteria isolated from BS showed a high destructive activity with respect to oil products can be explained by the following. It is known that in water-flooded oil fields, where the only source of carbon is oil, along with oiloxidizing microorganisms ("producers"), many chemoheterotrophic aerobic and anaerobic satellite microorganisms (dissipotrophs) can be distinguished that are not able to utilize oil components, but grow at the expense of products its degradation. Perhaps, among the bacteria isolated, there were just such satellite microorganisms.

Thus, as a result of the studies carried out, it was shown that BSs are a source of specialized microorganisms capable of decomposing various xenobiotics. At the same time, HOM dominate in microbial communities of BS. A wide substrate spectrum for petroleum hydrocarbons found in isolated bacteria indicates the prospects for using such microorganisms in technologies for microbial utilization of drilling waste.

\section{REFERENCES}

1. Achazi R.K. 2002. Invertebrates in risk assessment development of a test battery and of short term biotests for ecological risk assessment of soil. J. Soil Contaminat, 2(4), 174-178.

2. Bashan Y., Holguin G., De-Bashan L.E. 2004. Azospirillum-plant relationships: agricultural, physiological, molecular and environmental advances. Microbiology, 50, 521-577.

3. Benka-Coker M.O., Olumagin A. 1995. Waste drilling fluid-utilising microorganisms in a tropical mangrove swamp oilfield location. Bioresource Technology, 53, 211-215.

4. Choi Y.J. 1998. Effects of osmoprotectants on the growth and nitrogenase activity of Rhizobium and Azospirillum under osmotic stress. Agric. Chem. Biotechnol, 41, 53-59.
5. Dott W., Feidieker D., Kampfer P. 1989. Comparison of autochthonous bacteria and commercially available cultures with respect to their effectiveness in fuel oil. Industrial Microbiology and Biotechnology, 4(5), 365-374.

6. Fritsche W., Hofrichter M. 2000. Aerobic degradation by microorganisms in environmental processes. Soil Decontamination, 3, 146-155.

7. Haghighat S., et al. 2008. Ability of indigenous Bacillus licheniformis and Bacillus subtilis in microbial enhanced oil recovery. Intern. J. Syst. Bacteriol, 1, 385-390.

8. Jing W., Hongke X., Shaohui G. 2007. Isolation and characteristics of a microbial consortium for effectively degrading phenanthrene. Petroleum Sci, 4(3), 68-75.

9. Luz M., et al. 1997. A Rhodococcus species that thrives on medium saturated with liquid benzene. Microbiology, 7, 2975-2981.

10. Vinas M. 2002. Biodegradation of a crude oil by three microbial consortia of different origins and metabolic capabilities. Industrial Microbiology and Biotechnology, 28, 252-260.

11. Melnikov D.A et al. 2005. Distribution of signs of hydrocarbon degradation among heterotrophic microflora isolated from soil and oil sludge. Polythematic network electronic scientific. KubGAU magazine, 2, 1-13.

12. Loginov O.N. et al. 2002. Biopreparation "Lenoil" based on microorganisms-oil destructors. Chemical reagents, reagents and processes of low-tonnage chemistry. In: Proceedings of International Conference Ufa, Publishing House of UGU, 179-180.

13. Klyuyanova M.A. 2009. Development of the basis of a biological product for oil degradation in case of pollution of natural environments, $\mathrm{PhD}$ thesis, 120 .

14. Plotnikova E.G. 2010. Bacteria-destructors of aromatic hydrocarbons and their chlorine derivatives: diversity, features of metabolism, functional genomics, PhD thesis, 139.

15. Ilyina, E.G. 2002. Development of technology for biotreatment of oil and drilling wastes, $\mathrm{PhD}$ thesis, 185.

16. Astrov, N.G. et al.,1998. Development of bioconversion treatment of oily wastewater using the Cascade-Star system. In: Proceedings of International Scientific-Practical Conference "Water and Health'98”. OSU Publ. House, Odessa: 213-217. 